\title{
The Devonian nekton revolution
}

\author{
CHRISTIAN KLUG, BJÖRN KRÖGER, WOLFGANG KIESSLING, GARY L. MULLINS, THOMAS SERVAIS, \\ JIŘÍ FRÝDA, DIETER KORN AND SUSAN TURNER
}

\section{LETHAIA}

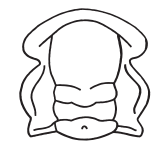

\begin{abstract}
Klug, C., Kröger, B., Kiessling, W., Mullins, G.L., Servais, T., Frýda, J., Korn, D. \& Turner, S. 2009: The Devonian nekton revolution. Lethaia, 10.1111/j.1502-3931.2009.00206.x

Traditional analyses of Early Phanerozoic marine diversity at the genus level show an explosive radiation of marine life until the Late Ordovician, followed by a phase of erratic decline continuing until the end of the Palaeozoic, whereas a more recent analysis extends the duration of this early radiation into the Devonian. This catch-all approach hides an evolutionary and ecological key event long after the Ordovician radiation: the rapid occupation of the free water column by animals during the Devonian. Here, we explore the timing of the occupation of the water column in the Palaeozoic and test the hypothesis that ecological escalation led to fundamental evolutionary changes in the mid-Palaeozoic marine water column. According to our analyses, demersal and nektonic modes of life were probably initially driven by competition in the diversity-saturated benthic habitats together with the availability of abundant planktonic food. Escalatory feedback then promoted the rapid rise of nekton in the Devonian as suggested by the sequence and tempo of water-column occupation. $\square$ Devonian, diversity, ecology, food webs, nekton, plankton, radiation.
\end{abstract}

Christian Klug [chklug@pim.uzh.ch], Paläontologisches Institut und Museum, Universität Zürich, Karl Schmid-Strasse 4, CH-8006 Zürich, Switzerland; Björn Kröger [bjoekroe@gmx.de], Wolfgang Kiessling [wolfgang.kiessling@museum.hu-berlin.de] and Dieter Korn [dieter.korn@museum.hu-berlin.de], Museum für Naturkunde, Humboldt-Universität zu Berlin, Invalidenstraße 43, D-10115 Berlin, Germany; Gary L. Mullins [acritarcha@ hotmail.com], Department of Geology, The University of Leicester, University Road, Leicester, LE1 7RH, UK; Thomas Servais [thomas.servais@univ-lille1.fr], Laboratoire de Paléontologie et Paléogéographie du Paléozö̈que, UMR 8157 du CNRS, Université des Sciences et Technologies de Lille, SN5 Cité Scientifique, F-59655 Villeneuve d'Ascq, France; Jiř́ Frýda [bellerophon@seznam.cz], Faculty of Environmental Science, Czech University of Life Sciences, Kamýcká 129, 16521 Praha 6 Suchdol, Czech Republic; Susan Turner [SueT@qm.qld.gov.au], School of Geosciences, Monash University, Box 28E, Vic 3800, and Queensland Museum Geosciences, 122 Gerler Road, Qld 4011, Australia; manuscript received on 9/4/2009; manuscript accepted on 10/9/2009.
Metazoans successively occupied various marine macroecological niches during the Early Palaeozoic (Sepkoski 1984; Stanley 2007; Servais et al. 2008, 2009). Metazoan benthos existed as early as the Neoproterozoic and with the beginning of the Phanerozoic, a benthic tiering evolved with forms extending into water levels above and below the sediment surface (Signor \& Brett 1984; Seilacher 1999; Dornbos \& Bottjer 2000; Dzik 2005; Bush et al. 2007). This includes the origin of the demersal mode of life, i.e. swimming animals that live close to the seafloor. Although small planktonic predators (i.e. passively drifting or migrating vertically) occurred already in the Cambrian (Butterfield 2001; Hu et al. 2007), it was not before the Ordovician that a vast number of planktonic metazoans (Bambach 1999; Rigby \& Milsom 2000; Servais et al. 2008) conquered the higher parts of the water column. The first active pelagic swimmers, i.e. true nekton, also occurred in this interval together with the Early Phanerozoic phytoplankton diversity maximum (Servais et al. 2008, 2009).
One of the first authors to discuss and analyse the Devonian 'faunal turnover' was Bambach (1999, p. 135). Instead of grouping the metazoans into benthic, demersal, planktonic and nektonic animals, he used the units 'Low Energy' and 'High Energy' Predators (p. 136), which show a similar change to the groups considered here, but he restricted his analyses to six groups: nautiloids, eurypterids and asteroids were placed within the 'Low Energy' Predators versus ammonoids, malacostracans and jawed fish, which he placed within the 'High Energy' Predators. On the one hand, his analyses already reflected the macroecological changes displayed by our analyses but on the other hand, he used quite different ecological aspects to classify his faunas. While Bambach's (1996, p. 136) approach focused on 'biomass, general physical activity, metabolic rates and the concomitant need for a level of food consumption sufficient for the support of metabolic needs', we included only non-benthic organisms according to habitat as well as swimming activity, and we included all well-documented groups 
with a non-benthic mode of life; we thus analysed a much larger data-set including substantial new information. The approach of Bambach et al. (2002) had again a different focus: They grouped the organisms 'as either passive (nonmotile) or active (motile)' (p. 6854). As we excluded, the motile benthos (e.g. gastropods and hyoliths) from our study, their results and conclusions also differ from those presented here.

Our aims were, accordingly, (1) to analyse this Devonian macroecological turnover using new data and new approaches as well as (2) to discuss the results of these analyses in the light of global ecological changes during the Palaeozoic.

\section{Methods}

We first grouped all higher-ranked taxa of nonbenthic metazoans according to their assumed dominant mode of life into demersal, plankton and nekton (Table 1; a discussion of the assignment to ecological megaguilds can be found below). We did not include cnidarian plankton such as scyphozoans and ctenophores because of their low diversity in the Devonian (probably because of a preservational bias). We then analysed the stratigraphical ranges of all genera comprising these ecological megaguilds based on Sepkoski's compendium (Sepkoski 2002) to assess their diversity trajectories at the stage level. Data from the Paleobiology Database (PaleoDB, http://paleodb.org/) were used to test if the patterns were matched by abundance data estimated from the number of occurrences of each megaguild. Although both Sepkoski's compendium and the PaleoDB contain taxonomic errors, these are unlikely to affect large-scale diversity patterns (Wagner et al. 2007). Sampling problems are largely taken into account by focussing on proportional rather than raw data (Madin et al. 2006) or by applying rarefaction analyses when detailed occurrence counts were available.

In addition to Sepkoski's compendium (Sepkoski 2002), unpublished or new databases were available on acritarchs (not included in Sepkoski's data) and several invertebrates and vertebrates (see below). These data are partially derived from our own investigations and were used to evaluate detailed ecological changes among Palaeozoic marine metazoans. Based on these data, we performed simple diversity analyses including counts of boundary-crossing genera of all groups. As we included rapidly evolving groups such as acritarchs, dacryoconarids and cephalopods in our study, we also tabulated diversity with taxa known from only one stratigraphical interval (singletons).

Table 1. Assignment of animal groups to ecological megaguilds.

\begin{tabular}{|c|c|c|c|c|c|}
\hline \multicolumn{2}{|c|}{ Demersal megaguild } & \multicolumn{2}{|c|}{ Plankton megaguild } & \multicolumn{2}{|l|}{ Nekton megaguild } \\
\hline Taxon & Explanation & Taxon & Explanation & Taxon & Explanation \\
\hline $\begin{array}{l}\text { Ascocerida } \\
\text { Discosorida } \\
\text { Oncocerida }\end{array}$ & $\begin{array}{l}\text { Coiled or curved shell, } \\
\text { position of hyponome, } \\
\text { occur in shallow water } \\
\text { facies, actualistic } \\
\text { comparison }\end{array}$ & Orthocerida & $\begin{array}{l}\text { Orthoconic to slightly } \\
\text { curved shells, secondary } \\
\text { deposits in } \\
\text { phragmocone rare, } \\
\text { vertical migrants } \\
\text { (undiff. muscle } \\
\text { attachment), occur in } \\
\text { black shales }\end{array}$ & $\begin{array}{l}\text { Ammonoidea Nautilida } \\
\text { Tarphycerida }\end{array}$ & $\begin{array}{l}\text { Differentiated muscle } \\
\text { attachment, coiled } \\
\text { shell, occur also in } \\
\text { black shales }\end{array}$ \\
\hline $\begin{array}{l}\text { Ellesmerocerida } \\
\text { Plectronocerida } \\
\text { Protactinocerida } \\
\text { Yanhecerida }\end{array}$ & $\begin{array}{l}\text { Usually breviconic with } \\
\text { short body chamber, } \\
\text { occur in shallow water } \\
\text { facies }\end{array}$ & $\begin{array}{l}\text { Dacryoconarida } \\
\text { Homoctenida }\end{array}$ & $\begin{array}{l}\text { Abundant in black } \\
\text { shales, occur in all } \\
\text { facies, too small for } \\
\text { active swimming }\end{array}$ & & \\
\hline $\begin{array}{l}\text { Actinocerida } \\
\text { Endocerida } \\
\text { Intejocerida }\end{array}$ & $\begin{array}{l}\text { Usually large orthocones } \\
\text { with expanded } \\
\text { siphuncles, in shallow } \\
\text { water deposits, often } \\
\text { ventrally flattened or } \\
\text { depressed shell }\end{array}$ & & & & \\
\hline $\begin{array}{l}\text { Radiodonta } \\
\text { Eurypterida }\end{array}$ & $\begin{array}{l}\text { Walking and swimming } \\
\text { appendages }\end{array}$ & & & & \\
\hline $\begin{array}{l}\text { Cephalochordata } \\
\text { Agnatha }\end{array}$ & $\begin{array}{l}\text { Flat body, mouth } \\
\text { orientation, actualistic } \\
\text { comparison with } \\
\text { lancelet }\end{array}$ & Graptoloidea & $\begin{array}{l}\text { Occur in black } \\
\text { shales, too small for } \\
\text { active swimming, } \\
\text { global distribution }\end{array}$ & $\begin{array}{l}\text { Acanthodii } \\
\text { Chondrichthyes } \\
\text { Osteichthyes, } \\
\text { Placodermi }\end{array}$ & $\begin{array}{l}\text { Occur in black shales, } \\
\text { actualistic comparison }\end{array}$ \\
\hline
\end{tabular}




\section{Demersal zone}

We assume that the following major taxa lived in demersal habitats: Among the nautiloids, all nautiloids originating during the Cambrian, the Actinocerida, Ascocerida, Discosorida, Ellesmerocerida, Endocerida, Lituitida and Oncocerida are here considered demersal (Table 2); this inference is based on the facies they occur in and morphological features such as coiling and position of hyponomic sinuses (Chen \& Teichert 1983; Stridsberg 1985; Westermann 1999; Kröger \&
Mutvei 2005). Most of the Radiodonta and Eurypterida are also thought to have lived in the demersal zone because of the presence of what probably were swimming and walking appendages. Agnathans (Galeaspida, Osteostraci and Pteraspidomorphi; Tables 3-5) most likely shared this habitat because of their usually dorsoventrally flattened body (Janvier 1996). Cephalochordata were probably demersal like their modern relative, the lancelet (Branchiostoma). Some Devonian fish traces provide evidence for a demersal habitat for the jawless fishes (Morrissey et al. 2006). As far as thelodont genera in the Devonian are concerned, they

Table 2. Diversity of mid-Palaeozoic Discosorida, Nautilida, Oncocerida and Tarphycerida. The data compilation was performed by B.K. (Kröger 2003, 2005, 2008), largely based on Sepkoski's raw data (2002).

\begin{tabular}{|c|c|c|c|c|c|c|c|c|c|}
\hline & Ludlow & Pridoli & Lochkovian & Pragian & Emsian & Eifelian & Givetian & Frasnian & Famennian \\
\hline Taxa & 84 & 60 & 71 & 59 & 84 & 107 & 88 & 69 & 78 \\
\hline Crossing lower boundary & 57 & 55 & 45 & 48 & 45 & 45 & 54 & 34 & 19 \\
\hline Crossing only lower boundary & 15 & 12 & 9 & 7 & 7 & 13 & 28 & 19 & \\
\hline Crossing only upper boundary & 13 & 2 & 12 & 3 & 7 & 22 & 8 & 4 & \\
\hline Crossing both boundaries & 42 & 43 & 36 & 41 & 38 & 32 & 26 & 15 & \\
\hline Singletons & 14 & 5 & 13 & 7 & 28 & 40 & 27 & 30 & \\
\hline FADs & 23 & 5 & 25 & 10 & 38 & 58 & 34 & 34 & 56 \\
\hline LADs & 30 & 15 & 23 & 14 & 36 & 50 & 54 & 46 & \\
\hline Mean standing diversity & 56 & 50 & 46.5 & 46 & 45 & 49.5 & 44 & 26.5 & \\
\hline Mean standing diversity + singletons $/ 3$ & 60.7 & 51.7 & 50.8 & 48.3 & 54.3 & 62.8 & 53 & 36.5 & \\
\hline Occurrences of species & 209 & 80 & 99 & 87 & 94 & 204 & 192 & 135 & 133 \\
\hline Species diversity at 70 occurrences (rarefied) & 42 & 38 & 41 & 29 & 49 & 48 & 41 & 40 & 49 \\
\hline
\end{tabular}

Table 3. Diversity of Devonian Pteraspidomorphi (heterostracans). The compilation was performed by B.K. (Kröger 2003, 2005), largely based on Sepkoski's (2002) raw data.

\begin{tabular}{|c|c|c|c|c|c|c|c|c|c|}
\hline & Wenlock & Ludlow & Pridoli & Lochkovian & Pragian & Emsian & Eifelian & Givetian & Frasnian \\
\hline Genera per stage & 13 & 11 & 21 & 29 & 13 & 5 & 3 & 6 & 4 \\
\hline Crossing lower boundary & 2 & 7 & 8 & 12 & 2 & 4 & 0 & 1 & 2 \\
\hline Crossing only lower boundary & 0 & 2 & 3 & 11 & 1 & 4 & 0 & 1 & 2 \\
\hline Crossing only upper boundary & 5 & 3 & 7 & 1 & 3 & 0 & 1 & 2 & 0 \\
\hline Crossing both boundaries & 2 & 5 & 5 & 1 & 1 & 0 & 0 & 0 & 0 \\
\hline Singletons & 6 & 1 & 6 & 16 & 8 & 1 & 2 & 3 & 2 \\
\hline LADs & 6 & 3 & 9 & 27 & 9 & 5 & 2 & 4 & 4 \\
\hline Mean standing diversity & 4.5 & 7.5 & 10 & 7 & 3 & 2 & 0.5 & 1.5 & 1 \\
\hline Mean standing diversity + singletons $/ 3$ & 6.5 & 7.8 & 12 & 12.3 & 5.7 & 2.3 & 1.2 & 2.5 & 1.7 \\
\hline
\end{tabular}

Table 4. Diversity of Devonian Cephalaspidomorphi. P. Janvier (Paris) kindly provided us with an unpublished personal data base which we were allowed to evaluate.

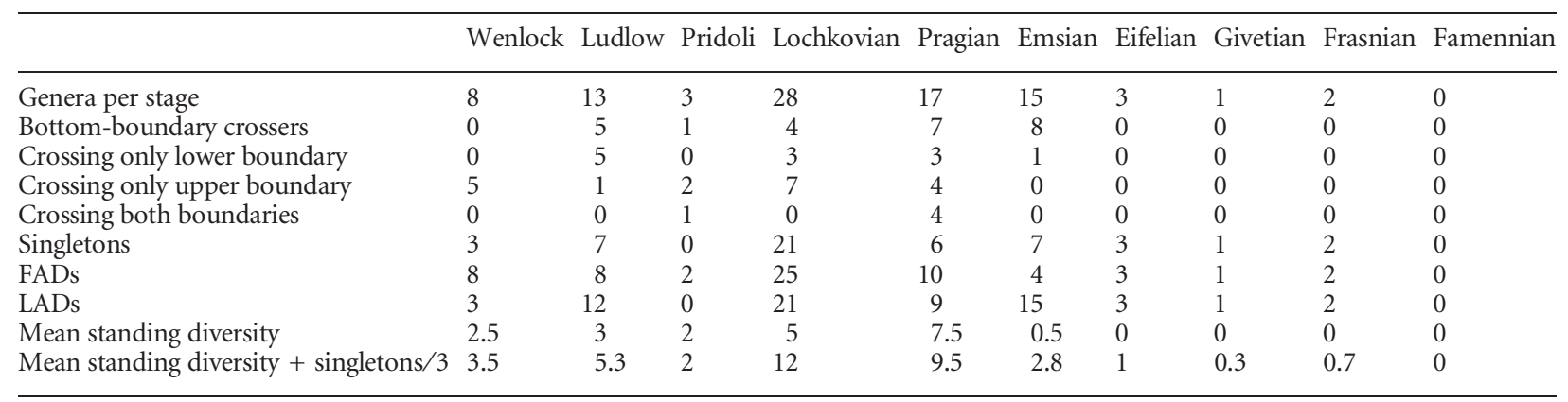


Table 5. Diversity of Devonian Galeaspida. P. Janvier (Paris) kindly provided us with an unpublished personal data base which we were allowed to evaluate and literature data (Zhu 2000; Zhu et al. 2000) were also included.

\begin{tabular}{|c|c|c|c|c|c|c|c|c|}
\hline & Llandovery & Wenlock & Ludlow & Pridoli & Lochkovian & Pragian & Emsian & Eifelian \\
\hline Genera per stage & 9 & 6 & 1 & 5 & 16 & 16 & 46 & 1 \\
\hline Bottom-boundary crossers & 9 & 3 & 1 & 1 & 5 & 3 & 1 & 0 \\
\hline Crossing only lower boundary & 6 & 3 & 0 & 0 & 4 & 3 & 0 & 0 \\
\hline Crossing only upper boundary & 3 & 1 & 0 & 1 & 2 & 0 & 0 & 0 \\
\hline Crossing both boundaries & 0 & 0 & 1 & 1 & 1 & 0 & 0 & 0 \\
\hline Singletons & 6 & 1 & 0 & 3 & 9 & 13 & 6 & 1 \\
\hline FADs & 9 & 3 & 0 & 4 & 11 & 13 & 6 & 1 \\
\hline LADs & 6 & 5 & 0 & 3 & 16 & 16 & 6 & 1 \\
\hline Mean standing diversity & 4.5 & 2 & 1 & 1.5 & 15 & 1.5 & 6 & 1 \\
\hline Mean standing diversity + singletons $/ 3$ & 6.5 & 2.3 & 1 & 2.5 & 18 & 19 & 8 & 1.3 \\
\hline
\end{tabular}

Table 6. Diversity of Devonian Thelodonti. Data from Märss et al. (2007).

\begin{tabular}{llllllll}
\hline & Lochkov & Pragian & Emsian & Eifelian & Givetian & Frasnian & Famennian \\
\hline Genera per stage & 23 & 7 & 5 & 5 & 1 & 2 & 0 \\
Bottom-boundary crossers & 8 & 5 & 3 & 5 & 1 & 1 & 0 \\
Crossing only lower boundary & 7 & 4 & 0 & 4 & 0 & 1 & 0 \\
Crossing only upper boundary & 4 & 2 & 2 & 0 & 0 & 0 & 0 \\
Crossing both boundaries & 1 & 1 & 3 & 1 & 1 & 0 & 0 \\
Singletons & 11 & 0 & 0 & 0 & 0 & 1 & 0 \\
FAD & 15 & 2 & 2 & 0 & 0 & 1 & 0 \\
LAD & 18 & 4 & 0 & 4 & 0 & 0 \\
Turnover & 33 & 6 & 2 & 4 & 0 & 2 & 0 \\
Mean standing diversity & 6.5 & 4 & 4 & 3 & 1 & 0 & 0 \\
Mean standing diversity + singletons/3 & 11.9 & 2 & 0 & 3.5 & 0.5 & 0.8 & 0 \\
\hline
\end{tabular}

essentially show the pattern discussed but only one genus extends through the Frasnian-Famennian boundary into the lower-middle Famennian (Märss et al. 2007). At present we include it in Turinia but this has become a waste basket taxon and will probably change. Thelodontidid and turiniid thelodont global distribution is different from other agnathans which might reflect larvae in the plankton, but as adults, many had a demersal and some possibly a nektobenthic mode of life (Table 6).

\section{Plankton}

We included graptoloids, dacryoconarids, homoctenids, orthocerids and bactritids as plankton (Tables 7-
10). Many members of these groups occur frequently in black shales and thus certainly lived in the water column. Most orthocerids were probably capable of minor horizontal movements but they were ineffective swimmers and migrated predominantly vertically and/or drifted passively (Hewitt \& Watkins 1980; Westermann 1999; Mutvei 2002; Kröger 2003, 2005; Kröger \& Mutvei 2005; Mutvei et al. 2007). This is suggested by their poorly differentiated muscle-attachment structures, the absence of significant endosiphonal or endocameral deposits and, in some cases, also shell morphology. Dacryoconarids and homoctenids (small conical shells of unclear systematic affinity) were too small to have been part of the nekton ( $\mathrm{Li}$ 2000; Berkyová et al. 2007). Graptoloids simply had a colony-morphology unsuitable for active swimming

Table 7. Diversity of mid-Palaeozoic acritarchs. Data from G.L.M.'s database.

\begin{tabular}{|c|c|c|c|c|c|c|c|c|}
\hline & Lochkovian & Pragian & Emsian & Eifelian & Givetian & Frasnian & Famennian & Tournaisian \\
\hline Species per stage max. & 220 & 120 & 180 & 137 & 165 & 289 & 251 & 128 \\
\hline Bottom-boundary crossers & 89 & 43 & 61 & 55 & 64 & 65 & 144 & 66 \\
\hline Crossing both boundaries & 31 & 40 & 41 & 53 & 43 & 41 & 56 & 3 \\
\hline Singletons & 65 & 4 & 23 & 6 & 39 & 93 & 74 & 15 \\
\hline FADs & 86 & 29 & 41 & 16 & 59 & 202 & 90 & 16 \\
\hline LADs & 123 & 7 & 43 & 8 & 60 & 117 & 162 & 78 \\
\hline Mean standing diversity + singletons $/ 3$ & 92.2 & 55.3 & 67.7 & 61 & 76.5 & 138.5 & 132.7 & 40 \\
\hline
\end{tabular}


Table 8. Diversity of Devonian radiolarians.

\begin{tabular}{|c|c|c|c|c|c|c|c|c|}
\hline & Lochkovian & Pragian & Emsian & Eifelian & Givetian & Frasnian & Famennian & Tournaisian \\
\hline Genera per stage & 8 & 8 & 8 & 9 & 10 & 12 & 25 & 26 \\
\hline Genera per stage + singletons & 8 & 8 & 8 & 9 & 10 & 15 & 31 & 27 \\
\hline Bottom-boundary crossers & 8 & 8 & 8 & 8 & 9 & 10 & 12 & 24 \\
\hline Singletons & 0 & 0 & 0 & 0 & 0 & 3 & 6 & 1 \\
\hline Mean standing diversity + singletons $/ 3$ & 8 & 8 & 8 & 8 & 9 & 12 & 20 & 22.3 \\
\hline Mean standing diversity & 8 & 8 & 8 & 8 & 9 & 11 & 18 & 22.0 \\
\hline
\end{tabular}

Table 9. Diversity of Devonian dacryoconarids and homoctenids. Most of the data (Li 2000; Berkyová et al. 2007) were collected by S. Berkyová.

\begin{tabular}{lccccccc}
\hline & Lochkovian & Pragian & Emsian & Eifelian & Givetian & Frasnian & Famennian \\
\hline Genera per stage & 13 & 23 & 23 & 15 & 10 & 5 & 2 \\
Bottom-boundary crossers & 0 & 13 & 15 & 11 & 9 & 5 & 2 \\
Crossing only lower boundary & 0 & 4 & 9 & 4 & 4 & 3 & 2 \\
Crossing only upper boundary & 12 & 7 & 5 & 2 & 0 & 0 & 0 \\
Crossing both boundaries & 0 & 8 & 6 & 7 & 5 & 2 & 0 \\
Singletons & 1 & 4 & 3 & 2 & 1 & 0 & 0 \\
FADs & 13 & 11 & 7 & 4 & 1 & 0 & 3 \\
LADs & 6 & 8 & 11 & 6 & 5 & 3.5 & 1 \\
Mean standing diversity & 6.3 & 13.5 & 13 & 10 & 7 & 3.5 & 1 \\
Mean standing diversity + singletons/3 & & 14 & 10.7 & 7.3 & \\
\hline
\end{tabular}

Table 10. Diversity of Devonian orthocerids and bactritids (Kröger 2005).

\begin{tabular}{|c|c|c|c|c|c|c|c|}
\hline & Lochkovian & Pragian & Emsian & Eifelian & Givetian & Frasnian & Famennian \\
\hline Genera per stage & 26 & 22 & 26 & 27 & 21 & 12 & 4 \\
\hline Bottom-boundary crossers & 19 & 19 & 18 & 20 & 15 & 11 & 4 \\
\hline Crossing only lower boundary & 3 & 2 & 3 & 8 & 7 & 7 & 0 \\
\hline Crossing only upper boundary & 3 & 1 & 5 & 3 & 3 & 0 & \\
\hline Crossing both boundaries & 16 & 17 & 15 & 12 & 8 & 4 & \\
\hline Singletons & 3 & 0 & 2 & 3 & 1 & 1 & \\
\hline FADs & 5 & 1 & 7 & 6 & 5 & 1 & 0 \\
\hline LADs & 5 & 2 & 5 & 10 & 9 & 8 & \\
\hline Mean standing diversity & 19 & 18.5 & 19 & 17.5 & 13 & 7.5 & \\
\hline Mean standing diversity + singletons $/ 3$ & 20 & 18.5 & 19.7 & 18.5 & 13.3 & 7.8 & \\
\hline Occurrences of species & 33 & 41 & 34 & 60 & 46 & 31 & 10 \\
\hline Species diversity at 10 occurrences (rarefied) & 8.1 & 5.8 & 7.8 & 7.4 & 7.2 & 4.7 & 4 \\
\hline
\end{tabular}

but have been shown convincingly to have lived as vertical migrants (Finney 1979; Rigby \& Rickards 1989).

The rich phytoplanktonic nutrient reservoir that existed from the Cambrian until at least the Late Devonian is reflected in the Early Devonian rise and extraordinary abundance of dacryoconarids and homoctenids which persisted until the Givetian (Middle Devonian; Li 2000; Berkyová et al. 2007) as well as in the high radiolarian diversity (new data) which increased from the Givetian until the Early Carboniferous.

\section{Nekton}

Here, we included the ammonoids, cartilaginous and bony jawed fishes, and most coiled nautiloids in the nekton (Tables 11-15). Ammonoids and coiled nautiloids are considered nektonic organisms because of their differentiated muscle-attachment structures and buoyancy devices, their occurrences in black shale facies, and actualistic comparisons (Doguzhaeva \& Mutvei 1991, 1996; Klug \& Korn 2004; Kröger et al. 2005). Recent studies have convincingly falsified the classical arguments against the high mobility of the ammonoids (Jacobs \& Chamberlain 1996) such as the absence of retractor muscles (see also Klug et al. 2008b) and the closer phylogenetic relationship to the coleoids than to the nautilids utilizing different musculature for propulsion. The presence of muscle attachments in ammonoids comparable with those of the nautilids has now been shown for various ammonoids (Doguzhaeva \& Mutvei 1991, 1996; Kröger et al. 2005; 
Table 11. Diversity of Devonian ammonoids (Korn \& Klug 2002; Korn \& Ilg 2007).

\begin{tabular}{|c|c|c|c|c|c|c|c|c|}
\hline & $\begin{array}{l}\text { Early } \\
\text { Emsian }\end{array}$ & $\begin{array}{l}\text { Late } \\
\text { Emsian }\end{array}$ & Eifelian & Givetian & Frasnian & $\begin{array}{l}\text { Early } \\
\text { Famennian }\end{array}$ & $\begin{array}{l}\text { Middle } \\
\text { Famennian }\end{array}$ & $\begin{array}{l}\text { Late } \\
\text { Famennian }\end{array}$ \\
\hline Genera per stage & 22 & 20 & 23 & 27 & 46 & 31 & 54 & 59 \\
\hline Crossing upper boundary & 6 & 6 & 4 & 3 & 5 & 2 & 7 & 2 \\
\hline Crossing only lower boundary & 0 & 5 & 6 & 4 & 2 & 5 & 2 & 7 \\
\hline Crossing only upper boundary & 6 & 5 & 4 & 3 & 5 & 2 & 7 & 2 \\
\hline Singletons & 16 & 9 & 12 & 20 & 40 & 24 & 45 & 50 \\
\hline FADs & 22 & 7 & 17 & 24 & 45 & 26 & 52 & 52 \\
\hline LADs & 16 & 14 & 19 & 24 & 42 & 29 & 47 & 57 \\
\hline Turnover & 38 & 21 & 36 & 48 & 87 & 55 & 99 & 109 \\
\hline Mean standing diversity & 3 & 6 & 5 & 3.5 & 4.5 & 3.5 & 4.5 & 4.5 \\
\hline $\begin{array}{l}\text { Mean standing } \\
\text { diversity }+ \text { singletons } / 3\end{array}$ & 8.3333 & 9 & 9 & 10.17 & 17.833 & 11.5 & 19.5 & 21.17 \\
\hline
\end{tabular}

Table 12. Diversity of Devonian acanthodians. The data of this table were extracted from Denison (1979).

\begin{tabular}{|c|c|c|c|c|c|c|c|}
\hline & Lochkov & Prag & Emsian & Eifelian & Givetian & Frasnian & Famennian \\
\hline Genera per stage & 16 & 18 & & 15 & 11 & 13 & 6 \\
\hline Crossing only lower boundary & 8 & 9 & 8 & 12 & 10 & 6 & 5 \\
\hline Crossing only upper boundary & 9 & 7 & 12 & 10 & 6 & 5 & 4 \\
\hline Crossing both boundaries & 6 & 5 & 7 & 7 & 5 & 3 & 3 \\
\hline Singletons & 5 & 6 & 1 & 1 & 1 & 6 & 0 \\
\hline FADs & 8 & 8 & 5 & 4 & 1 & 5 & 1 \\
\hline Mean standing diversity & 9 & 9 & 9 & 10 & 7 & 4 & 5 \\
\hline Mean standing diversity + singletons $/ 3$ & 10 & 11 & 9 & 10 & 7 & 6 & 5 \\
\hline
\end{tabular}

Table 13. Diversity of Devonian placoderms. The data of this table were extracted from Denison (1978) and Carr (1995).

\begin{tabular}{lccccccc}
\hline & Lochkovian & Pragian & Emsian & Eifelian & Givetian & Frasnian & Famennian \\
\hline Genera per stage & 31 & 50 & 55 & 53 & 66 & 94 & 32 \\
Crossing lower boundary & 0 & 20 & 20 & 8 & 33 & 20 & 17 \\
Crossing upper boundary & 20 & 20 & 8 & 33 & 20 & 17 & 4 \\
Crossing only lower boundary & 0 & 8 & 16 & 3 & 21 & 14 & 13 \\
Crossing only upper boundary & 20 & 9 & 5 & 32 & 7 & 12 & 0 \\
Crossing both boundaries & 0 & 10 & 3 & 4 & 13 & 6 & 4 \\
Singletons & 11 & 17 & 27 & 15 & 25 & 62 & 14 \\
FADs & 31 & 26 & 32 & 47 & 32 & 74 & 14 \\
LADs & 11 & 25 & 43 & 18 & 46 & 76 & 27 \\
Mean standing diversity & 10 & 18.5 & 13.5 & 21.5 & 27 & 19 & 10.5 \\
Mean standing diversity + singletons/3 & 13.67 & 24.17 & 22.5 & 26.5 & 35.33 & 39.67 & 15.167 \\
Occurrences & 12 & 41 & 49 & 97 & 104 & 236 & 93 \\
\hline
\end{tabular}

Table 14. Diversity of Devonian sharks. M. Ginter (Warszawa) allowed us to use his unpublished database on the occurrences of sharks (Ginter et al. 2008). We also used data from Zangerl (1981) and from S.T.

\begin{tabular}{llllllrr}
\hline & Lochkovian & Pragian & Emsian & Eifelian & Givetian & Frasnian & Famennian \\
\hline Genera per stage & 2 & 0 & 2 & 1 & 8 & 10 & 21 \\
Bottom-boundary crossers & 0 & 0 & 0 & 1 & 1 & 4 & 6 \\
Top-boundary crossers & 0 & 0 & 1 & 1 & 4 & 6 & 12 \\
Crossing only lower boundary & 0 & 0 & 0 & 0 & 1 & 2 & 4 \\
Crossing only upper boundary & 0 & 0 & 1 & 0 & 4 & 4 & 10 \\
Crossing both boundaries & 0 & 0 & 0 & 1 & 0 & 2 & 2 \\
Singletons & 1 & 0 & 1 & 0 & 3 & 7 & 6 \\
FADs & 2 & 0 & 2 & 0 & 4 & 14 \\
LADs & 2 & 0 & 1 & 0 & 4 & 9 \\
Mean standing diversity & 0 & 0 & 0.5 & 1 & 2.5 & 5 & 8.5 \\
Mean standing diversity + singletons/3 & 0.3 & 0 & 1 & 1 & 4 & 6 & 11 \\
\hline
\end{tabular}


Table 15. Diversity of Devonian bony fish. The data compilation was performed by B.K. (Kröger 2005) based on Sepkoski's raw data (2002). In Fig. 2 of the main text, two curves of Carr (1995) are reproduced showing the diversity of sarcopterygian and actinopterygian genera per stage.

\begin{tabular}{|c|c|c|c|c|c|c|c|}
\hline & Lochkovian & Pragian & Emsian & Eifelian & Givetian & Frasnian & Famennian \\
\hline Genera per stage & 3 & 4 & 5 & 11 & 15 & 21 & 14 \\
\hline Bottom-boundary crossers & 0 & 1 & 2 & 4 & 9 & 11 & 8 \\
\hline Top-boundary crossers & 1 & 2 & 4 & 9 & 11 & 8 & 1 \\
\hline Crossing only lower boundary & 0 & 1 & 0 & 1 & 4 & 4 & 7 \\
\hline Crossing only upper boundary & 1 & 2 & 2 & 6 & 6 & 1 & 0 \\
\hline Crossing both boundaries & 0 & 0 & 2 & 3 & 5 & 7 & 1 \\
\hline Singletons & 2 & 1 & 1 & 1 & 0 & 9 & 6 \\
\hline FADs & 3 & 3 & 3 & 7 & 6 & 10 & 6 \\
\hline LADs & 2 & 2 & 1 & 2 & 4 & 13 & 13 \\
\hline Mean standing diversity & 0.5 & 1.5 & 3 & 6.5 & 10 & 9.5 & 4.5 \\
\hline Mean standing diversity + singletons $/ 3$ & 1.2 & 1.8 & 3.3 & 6.8 & 10 & 12.5 & 6.5 \\
\hline
\end{tabular}

Klug et al. 2008b) and the idea that a coleoid mantle was hidden in an ammonoid shell is not supported for phylogenetic reasons since the body chamber was reduced long after the ammonoids had evolved from the bactritoids (Fuchs 2006; Kröger \& Mapes 2007).

The coiled Tarphycerida and Nautilida are interpreted as nektobenthic or nektoplanktonic based on actualistic comparision of the shell form, muscleattachment structures and position of the hyponome (Westermann 1999; Kröger \& Mutvei 2005).

Among Devonian cephalopods, several striking evolutionary inventions are apparent. During the Early Devonian, the ammonoids, one of the most important groups of fossil marine invertebrate metazoans, evolved from bactritoids (Kröger \& Mapes 2007) which had, in turn, just evolved from the orthocerids (Hewitt \& Watkins 1980; Sepkoski 2002; Kröger \& Mutvei 2005; Kröger \& Mapes 2007; Kröger 2008). While the diversity and abundance of most cephalopods with straight conical or incompletely coiled shells decreased significantly towards the end of the Devonian, groups with adaptations to active, horizontal swimming life modes began to diversify in the Early Devonian. In addition to the bactritids and ammonoids, the coleoids (squids and octopods: Fuchs 2006; Kröger \& Mapes 2007), or at least their ancestors, evolved. While the nautiloids produced conch morphologies strikingly similar to the earliest ammonoids, the coleoids embarked on a differing strategy by later forming internal shells, the only successful strategy with respect to modern cephalopods. Interestingly, shell coiling or an increase in shell coiling occurred in such different groups as in dacryoconarids, gastropod larvae, bactritoids and ammonoids, both juvenile and adult. This can be interpreted as a reaction to the increasing predation pressure (Nützel \& Frýda 2003).
Early Palaeozoic marine vertebrate remains belong predominantly to the agnathans (jawless fishes). Early jawed fishes (Gnathostomata) are rarely documented from strata older than the Silurian (Gagnier 1989; Janvier 1996; Sansom \& Smith 2001). Marine gnathostome diversity increased explosively in the Mid Devonian with the radiations of placoderms, cartilaginous and bony fishes (Denison 1978, 1979; Zangerl 1981; Cloutier \& Forey 1991; Ginter et al. 2008). Remarkably, these evolutionary patterns coincided with some crucial morphological and ecological alterations (Long et al. 2008). Laterally compressed and thus nektonic body forms became more prevalent than the dorsoventrally flattened forms adapted to a predominantly demersal to benthic mode of life (Janvier 1996). Diversification trends can be grouped according to life habits: (1) demersal forms that display a clear diversity decrease, and in some cases extinction, towards the end of the Devonian (many jawless fishes); (2) nektonic forms, which exhibit low diversity in the Early Devonian, became highly diverse towards the end of the Devonian, and survived the end-Devonian extinctions with little or no loss (most jawed fishes) and (3) intermediate forms which were neither clearly demersal nor truly independent from the seafloor (acanthodians and placoderms). The data presented here require new analyses in the future which incorporates latest publications and results from research in progress (e.g. placoderm data are currently being revised by M. Rücklin, Bristol; reasonably new data were published by Long 1993; Carr 1995 and Blieck \& Turner 2000 and were included in our analyses).

The diversity curves of the acritarchs, ammonoids, placoderms, bony and cartilaginous fish track roughly parallel throughout the Devonian with maxima in the Late Devonian, whereas the diversity of jawless fishes and acanthodians fluctuated in different ways. 


\section{Additional groups}

Diversity data of the radiodonts, the eurypterids and graptoloids were extracted from Sepkoski's compendium (2002) and the Paleobiology Database. Gastropods with openly coiled protoconchs formed a considerable, sometimes even dominant, part of Ordovician and Silurian gastropod communities. During the Early Devonian, their number rapidly decreased and their embryonic shells became on average smaller (Nützel \& Frýda 2003; Nützel et al. 2007; Frýda et al. 2008). These macroevolutionary trends were followed by the Late Palaeozoic radiation of Neritimorpha, Caenogastropoda and Heterobranchia. Thus, the Devonian was the period which determined the composition of all post-Palaeozoic gastropod faunas.

\section{Results and discussion}

Both the diversity and abundance data suggest an initial scarcity of macroplankton and nekton, an Ordovician plankton radiation and a Devonian nekton revolution (Figs 1, 2); this is in accordance with the results of Bambach (1999). Although there seems to be a greater proportion of plankton in the early Palaeozoic according to abundance data (Fig. 1B), this may largely reflect differences in the documentation of demersal and planktonic groups in the PaleoDB.

The diversity of acritarchs was clearly lower in the Devonian than in the Ordovician but still high compared with the late Palaeozoic (Servais et al. 2008). During the Late Devonian, acritarchs experienced a last radiation prior to the subsequent strong decline ('phytoplankton blackout'; Mullins \& Servais 2008). Most important groups of Devonian invertebrate

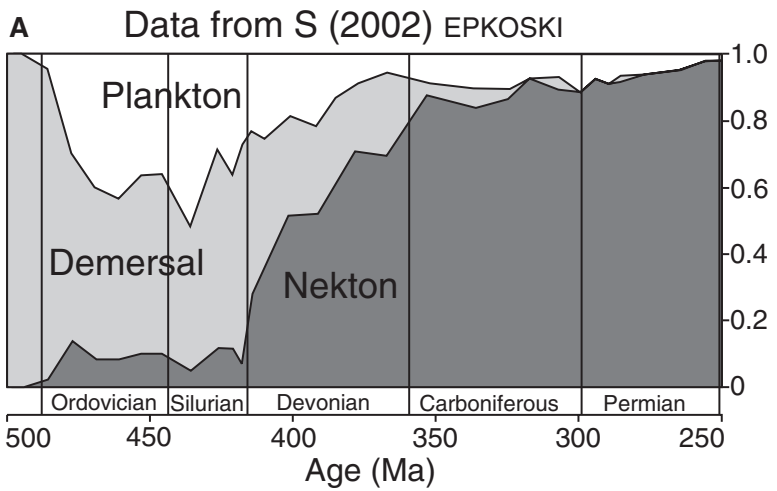

meso- and macro-zooplankton are not only morphologically similar (bactritoids, dacryoconarids, homoctenids, orthocerids) but also declined synchronously in diversity towards the end of the Devonian, similar to jawless fish diversity (e.g. Janvier 1996; Märss et al. 2007). Some nektonic groups with a close affinity to the benthos such as many nautiloids, acanthodians and placoderms behaved differently (e.g. Long 1993; Bambach 1999). They underwent minor extinctions and radiations during the Devonian but, except for the placoderms, persisted much longer than the endDevonian. Taken together, the nektonic groups display a rising diversity through most of the Devonian. Although they suffered during the Late Devonian mass extinctions to a varying degree, they continued to radiate and became highly diverse in the Late Devonian and Early Carboniferous. Remarkably, the Midto Late Devonian generic diversification of the nekton was delayed compared with the origins of most of the higher taxa.

After the Cambrian explosion (Seilacher 1999; Butterfield 2001; Hu et al. 2007) and the Great Ordovician diversification (Turner et al. 2004; Harper 2006; Servais et al. 2008, 2009), all nektonic organisms display a steep diversity increase from the Late Silurian to the Early Carboniferous at the expense of demersal and planktonic forms (compare Bambach 1983, 1999). This is accompanied by the radiation of radiolarians and various mollusc clades with planktotrophic juveniles or larvae (cephalopods, gastropods and perhaps bivalves).

For the explanation of the simultaneous explosive diversification of the nekton at the cost of various planktonic and demersal benthic groups, three hypotheses are available:

1. Eutrophication by increasing organic input because of the steady rise of land plants (Algeo

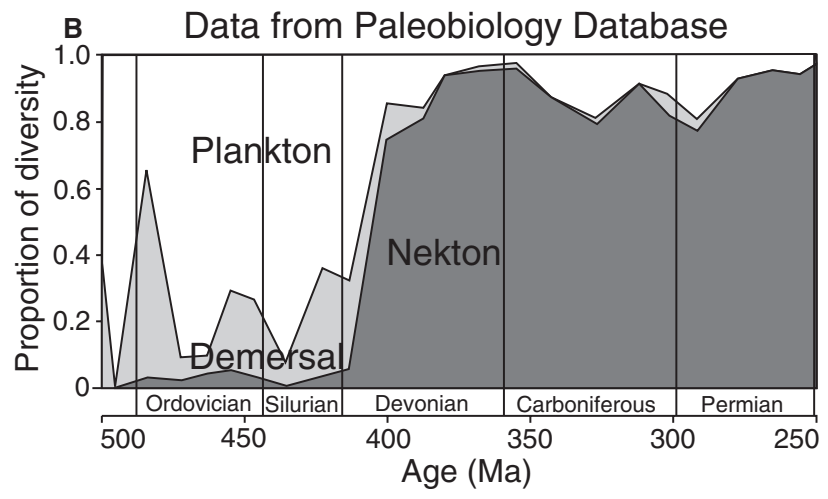

Fig. 1. Patterns of diversity and proportional abundance of demersal organisms, plankton and nekton in the Palaeozoic. A, diversity based on Sepkoski's data resolved to geological stages (Sepkoski 2002). B, occurrence counts from the Paleobiology Database resolved to 10 myr intervals. 


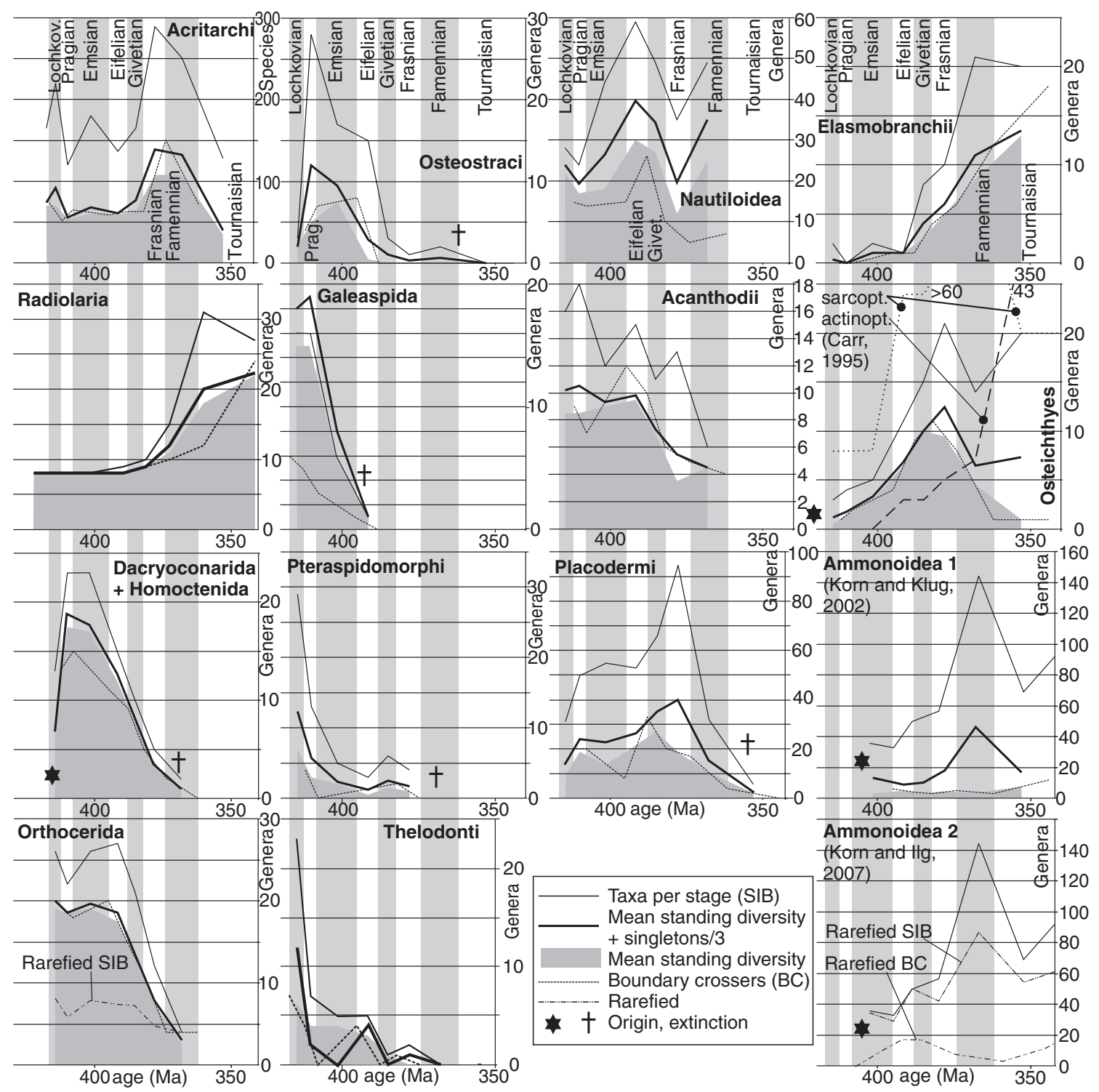

Fig. 2. Diversification of various higher rank taxa of phytoplankton, zooplankton, demersal and pelagic nekton in the Devonian and Early Carboniferous (for data see Tables 2-15).

et al. 1998), which induced a plankton bloom. The continuously high abundance of primary producers and the radiation of radiolarians (Fig. 2) fostered the diversification and radiation throughout marine food webs. Because of increasing competition in all habitats, the mobility increased simultaneously in various groups: nektonic ammonoids evolved via bactritoids from planktonic orthocerids (Klug \& Korn 2004), gnathostomes replaced demersal agnathans and nektonic nautilids from demersal oncocerids. Assuming this hypothesis is correct, one would expect a parallel diversification of nektonic groups and a subsequent plankton decrease.
2. Repeated and lasting anoxia throughout the Silurian and Devonian, caused by organic input (Algeo et al. 1998), caused selection in favour of non-benthic and -demersal life styles. If correct, mainly benthic and demersal groups should decline in diversity while nekton and plankton are less affected.

3. The free water column served as refuge from benthic and demersal predation pressure (Signor \& Vermeij 1994) and the Devonian Nekton Revolution (compare Vermeij's 1977) can be interpreted as reflecting an escalation at the bottom, forcing an invasion of benthic or demersal organisms into the free water column. Especially, 
the radiation of gnathostomes then increased predatory pressure on cephalopods, selecting for higher mobility (Klug \& Korn 2004; Kröger 2005). Assuming this hypothesis is correct, an initial high diversity in the demersal zone, followed by a radiation of some transitional demersal to pelagic-nektonic predators, again followed by a nekton diversification and a plankton decrease, would be expected.

The first hypothesis is corroborated by the radiation of molluscs with planktotrophic larvae and juveniles; profound changes in larval morphology and thus, reproductive and larval strategies among many molluscs began in the latest Cambrian and intensified during the Devonian (House 1996; Nützel \& Frýda 2003). Morphological adaptations of gastropod larvae and juvenile ammonoids to changes in the planktonic habitat are indicated by the closure of a larval or early juvenile umbilical opening, size-decrease of the larval or embryonic shell and occurrences of their shells in anoxic environments (Nützel \& Frýda 2003). Regional faunal analyses of the Moroccan Lower Devonian (Klug et al. 2008a) have shown that bivalve associations change from palaeotaxodont-dominated towards pteriomorph-dominated with perhaps planktotrophic larvae (Jablonski \& Lutz 1983). Therefore, an increasing proportion of larvae and juveniles from many important mollusc groups fed probably on plankton during the Devonian (Jablonski \& Lutz 1983). There is, however, no cross-correlation between originations and extinctions of phytoplankton and the zooplankton $(R=0.2$ and 0.38 , respectively, not significant) and thus, the first hypothesis is insufficient to explain the observed diversity fluctuations.

Lasting and repeated anoxic episodes are well-documented for the Devonian (Joachimski \& Buggisch 1993; Algeo et al. 1998). The main prediction drawn from the second hypothesis would be an extinction of all forms that lived close to the seafloor and were unable of escaping into higher, well-oxygenated water levels. Phytoplankton, zooplankton and nekton should be less affected by anoxia-induced extinctions. Nevertheless, this hypothesis fails to explain why the nekton radiation begins clearly before the most significant anoxia of the end-Givetian and -Frasnian.

The third hypothesis implies an initially high abundance and diversity of organisms in the demersal zone, followed by a selection for a mobility increase, ultimately leading to the rise of descendants of demersal organisms. This is in accordance with the observed diversity and occurrence fluctuations. Around the Silurian-Devonian boundary, the predominantly demersal jawless fish were rather diverse (Janvier 1996). In general, nektonic organisms with some demersal affinity such as several groups of nautiloids, acanthodians, placoderms and thelodonts display repeated minor diversifications and extinctions. The acanthodians have their maximum diversity in the Early Devonian, followed by a long-term decline. Many placoderms had thick bony armour and are morphologically intermediate between dorsoventrally flattened agnathans and laterally compressed bony fish, indicating a demersal to nektonic habitat (Janvier 1996). These mobile predators possibly suppressed many demersal animals (such as some cephalopods). The placoderm diversity peak (Fig. 2) predates the diversity and abundance maxima of the perhaps more meso- to epipelagic nekton such as some derived nautiloids (Kröger 2005), ammonoids (Klug \& Korn 2004), chondrichthyans (sharks and relatives; Miller et al. 2003; Ginter et al. 2008) and bony fish. Potentially, the nektonic predators subsequently suppressed representatives of the zooplankton, causing a partial zoo- and phytoplankton extinction (graptoloids, dacryoconarids, homoctenids, 'phytoplankton blackout') or at least profound changes. Simultaneously, the proportional diversity of benthos decreased relative to that of inhabitants of the water column (Fig. 3).

\section{Tests}

We tested our conclusions by plotting the proportional diversity of benthic animals versus those inhabiting the water column (Fig. 3). The resulting graph clearly shows that diversity changes among taxa inhabiting the water column cannot be explained simply by a general increase in the diversity of marine taxa.

Additionally, we produced regressions for boundary crossers, genera with and without singletons for all marine genera, benthos only and nekton only (Fig. 4). The regressions support our conclusions that the diversity of nekton increases at the cost of other marine genera including benthos and plankton.

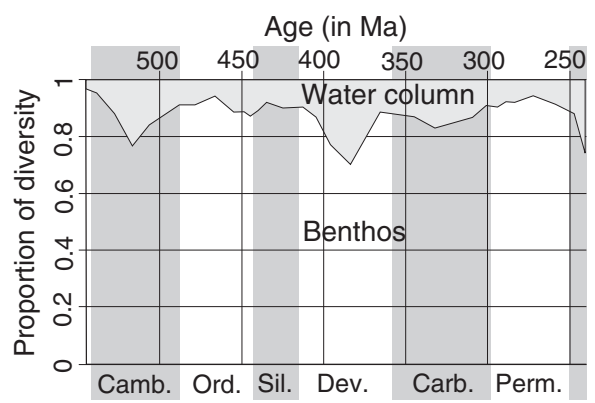

Fig. 3. Proportional diversity of benthic animals versus those inhabiting the water column throughout the Palaeozoic (Sepkoski 2002). 


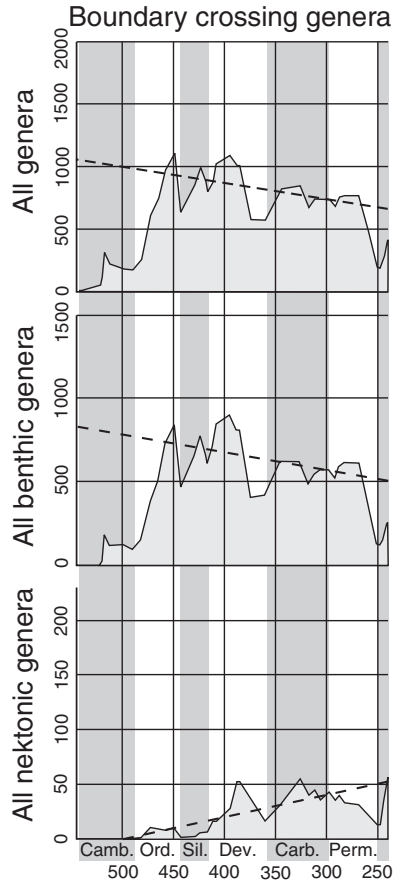

Genera with singletons

Genera without singletons
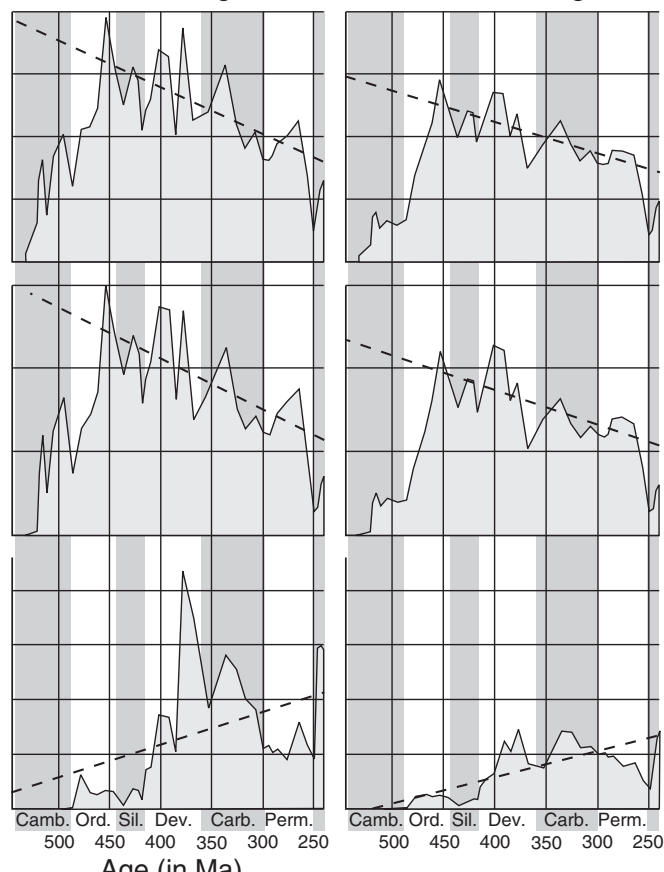

Fig. 4. Boundary-crossing marine genera throughout the Palaeozoic with the regression from the Caradoc to the Guadalupian (Sepkoski 2002). Boundary crossers, all genera with and without singletons of all marine genera, of all benthic genera and all nektonic genera are shown.

\section{Conclusions}

Major macroecological changes usually require some kind of trigger: The appearance of early mobile predators induced the evolution of skeletons and thus the Cambrian radiation, the Ordovician abundance of microplankton formed the basis for the radiation of larger plankton, the Ordovician to Devonian radiation of land plants enabled animals to follow on land. The

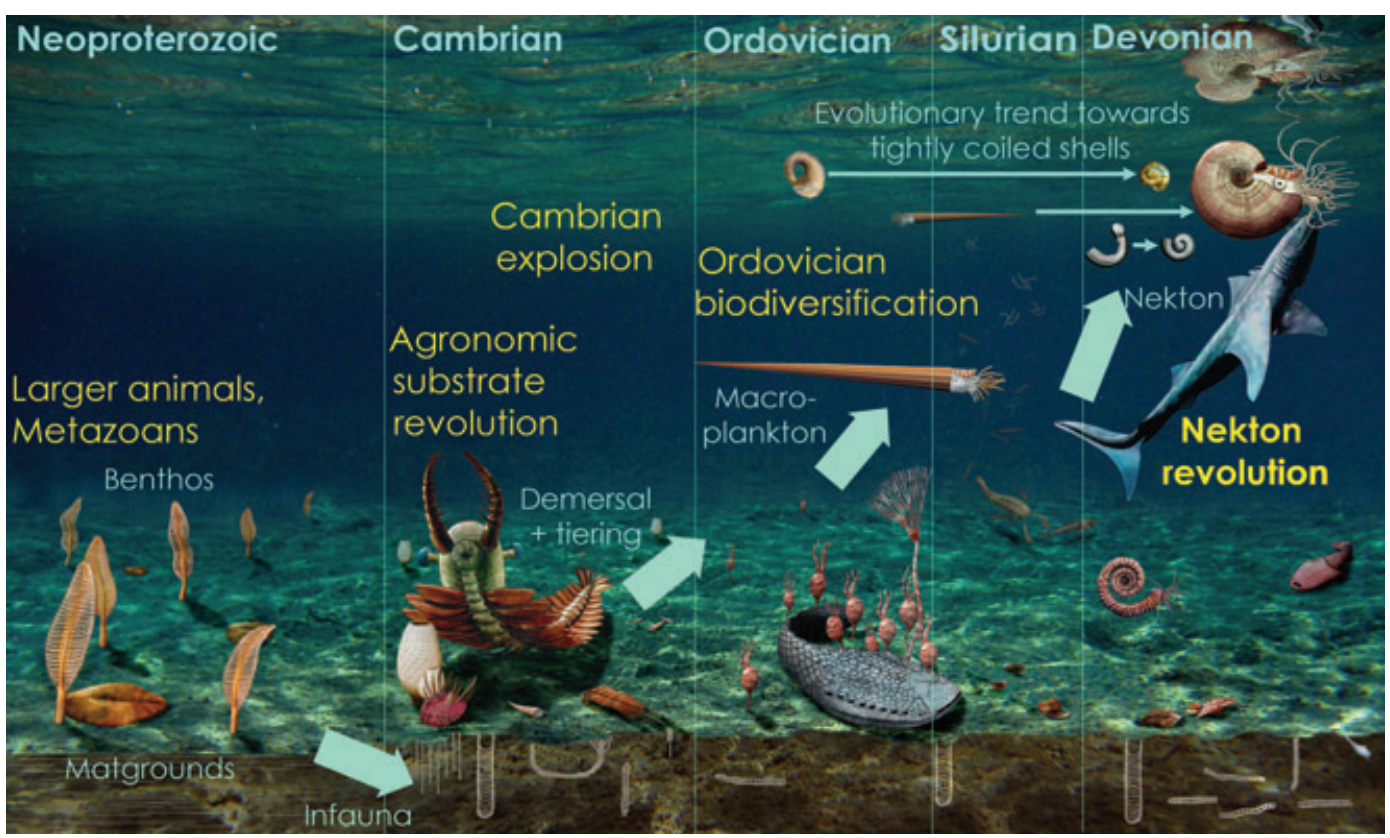

Fig. 5. Macroecological steps in the evolution of Palaeozoic marine food webs. 
evolutionary acquisition of the capability to swim actively in the pelagic realm thus followed the evolution of demersal and planktonic innovations, which occurred in several groups of macroscopic metazoans more or less simultaneously in the Cambrian and Ordovician (e.g. various arthropods, early cephalopods and graptoloids). The timing of diversification of various demersal and nektonic groups suggests that the Devonian Nekton Revolution was initiated by an escalation in the benthic and demersal zones (Fig. 5). The synchronous decline of benthic animals (Fig. 3) might be sufficient to explain why the overall diversity is not strongly affected. Increasing nutrient supply from the increasing terrestrial biomass probably supported the diversification of microplankton, organisms with planktotrophic larvae (Cambrian pelagic predators are here considered as parts of the plankton because of their small size; compare Butterfield 2001 and $\mathrm{Hu}$ et al. 2007) and nekton, which suppressed many demersal organisms and the macroplankton from their habitats. Consequently, among the marine metazoans, almost only nektonic predators of most scales and the diverse benthos remained following the explosive nekton radiation in the Early Devonian while the proportion of demersal and planktonic taxa decreased dramatically.

Acknowledgements. - We thank M. Rücklin (Bristol) for information on placoderms. A. Nützel (Munich) and two anonymous reviewers provided valuable comments. C.K. was supported by the Swiss National Science Foundation (project No. 200021113956/1). Synthesys funded a trip to Berlin by C.K., representing the starting point for this project. G.L.M. thanks the Leverhulme Trust (grant F/00212/F, awarded to R. J. Aldridge) and W.K. the Volkswagen-Stiftung. S.T. thanks for the opportunity to work as a guest researcher at the Institut für Geowissenschaften (Tübingen). This study is also a contribution to IGCP projects 491 and 503. J. Krriž shared his knowledge of Devonian bivalve ecology and M. Ginter made his shark occurrence data available. P. Janvier (Paris) generously let us use his diversity database of jawless fish. K. De Baets (Zürich) also discussed the manuscript with us.

\section{References}

Algeo, T.J., Scheckler, S.E. \& Scott, A.C. 1998: Terrestrial-marine teleconnections in the Devonian: links between the evolution of land plants, weathering processes, and marine anoxic events. Philosophical Transactions: Biological Sciences 353, 113-130.

Bambach, R.K. 1983: Ecospace utilization and guilds in marine communities through the Phanerozoic. In Tevesz, J.S., McCall, P.L. (eds): Biotic Interactions and Fossil Communities, 719-746. Plenum Press, New York \& London.

Bambach, R.K. 1999: Energetics in the global marine fauna: a connection between terrestrial diversification and change in the marine biosphere. Geobios 32, 131-144.

Bambach, R.K., Knoll, A.H. \& Sepkoski, J.J. Jr. 2002: Anatomical and ecological constraints on Phanerozoic animal diversity in the marine realm. PNAS 99, 6854-6858.

Berkyová, S., Frýda, J. \& Lukeš, P. 2007: Unsuccessful predation on Middle Paleozoic plankton: shell injury and anomalies in Devonian dacryoconarid Tentaculites. Acta Palaeontologica Polonica $52,407-412$.
Blieck, A. \& Turner, S. 2000: Palaeozoic vertebrate biochronology and global marine-non-marine correlation. Final report of IGCP 328. Courier Forschungsinstitut Senckenberg 223, 1-575.

Bush, A.M., Bambach, R.K. \& Daley, G.M. 2007: Changes in theoretical ecospace utilization in marine fossil assemblages between the mid-Paleozoic and late Cenozoic. Paleobiology 33, 76-97.

Butterfield, N.J. 2001: Ecology and evolution of the Cambrian plankton. In Zhuravlev, A.Y., Riding, R. (eds): The Ecology of the Cambrian Radiation, 200-216. Columbia University Press, New York.

Carr, R.K. 1995: Placoderm diversity and evolution. Bulletin $d u$ Muséum d'Histoire naturelle, Paris, 4e sér. 17 C, 85-125.

Chen, J.-Y. \& Teichert, C. 1983: Cambrian Cephalopoda of China. Palaeontographica A 181, 1-102.

Cloutier, R. \& Forey, P.L. 1991: Diversity of extinct and living actinistian fishes (Sacropterygii). Environmental Biology of Fishes 32, 59-74.

Denison, R.H. 1978: Placodermi. In Schultze, H.-P. (ed.): Handbook of Paleoichthyology, 2, 1-128. Fischer, Stuttgart \& New York.

Denison, R.H., 1979: Acanthodii. In Schultze, H.-P. (ed.): Handbook of Paleoichthyology, 2, 1-62. Fischer, Stuttgart \& New York.

Doguzhaeva, L.A. \& Mutvei, H. 1991: Organization of the soft body in Aconeceras (Ammonitina), interpreted on the basis of shell morphology and muscle scars. Palaeontographica A 218, $17-33$.

Doguzhaeva, L.A. \& Mutvei, H. 1996: Attachment of the body to the shell in ammonoids, In Landman, N.H., Tanabe, K., Davis, R.A. (eds): Ammonoid Paleobiology, 44-64. Plenum, New York \& London.

Dornbos, S.Q. \& Bottjer, D.J. 2000: Evolutionary paleoecology of the earliest echinoderms: Helicoplacoids and the Cambrian substrate revolution. Geology 28, 839-842.

Dzik, J. 2005: Behavioral and anatomical unity of the earliest burrowing animals and the cause of the 'Cambrian explosion'. Paleobiology 31, 503-521.

Finney, S.C. 1979: Mode of life of planktonic graptolites; flotation structure in Ordovician Dicellograptus sp. Paleobiology 5, 31-39.

Frýda, J., Nützel, A. \& Wagner, P.J. 2008: Paleozoic gastropods. In Ponder, W., Lindberg, D.L. (eds): Phylogeny and Evolution of the Mollusca, 237-268. University of California Press, Berkeley.

Fuchs, D. 2006: Fossil erhaltungsfähige Merkmalskomplexe der Coleoidea (Cephalopoda) und ihre phylogenetische Bedeutung. Berliner Paläobiologische Abhandlungen 8, 1-122.

Gagnier, P.-Y. 1989: The oldest vertebrate: a 470-million-year-old jawless fish, Sacabambaspis janvieri, from the Ordovician of South America. National Geographic Research 5, 250-253.

Ginter, M., Hampe, O. \& Duffin, C. 2008: Chondrichthyes (Paleozoic Elasmobranchii: teeth). In Schultze, H.-P. (ed.): Handbook of Paleoichthyology 3D, 1-128. Fischer, Stuttgart \& New York.

Harper, D.A.T. 2006: The Ordovician biodiversification: setting an agenda for marine life. Palaeogeography, Palaeoclimatology, Palaeoecology 232, 148-166.

Hewitt, R.A. \& Watkins, R. 1980: Cephalopod ecology across a late Silurian shelf tract. Neues Jahrbuch für Geologie und Paläontologie, Abhandlungen 160, 96-117.

House, M.R. 1996: Juvenile goniatite survival strategies following Devonian extinction events. In Hart, M.B. (ed.): Biotic Recovery From Mass Extinction Events, 163-185. Geological Society Special Publication 102, Plymouth, UK.

Hu, S., Steiner, M., Zhu, M., Erdtmann, B.-D., Luo, H., Chen, L. \& Weber, B. 2007: Diverse pelagic predators from the Chengjiang Lagerstätte and the establishment of modern-style pelagic ecosystems in the early Cambrian. Palaeogeography, Palaeoclimatology, Palaeoecology 254, 307-316.

Jablonski, D. \& Lutz, R.A. 1983: Larval ecology of marine benthic invertebrates: paleobiological implications. Biological Reviews 58, 21-89.

Jacobs, D.K. \& Chamberlain, J.A. Jr. 1996: Buoyancy and hydrodynamics in ammonoids. In Landman, N.H., Tanabe, K., Davis, R.A. (eds): Ammonoid Paleobiology, 170-224. Plenum, New York \& London. 
Janvier, P. 1996: Early Vertebrates. Oxford Monographs on Geology and Geophysics 33, 393 pp. Clarendon Press, Oxford.

Joachimski, M.M. \& Buggisch, W. 1993: Anoxic events in the late Frasnian - causes of the Frasnian-Famennian faunal crisis? Geology $21,675-678$.

Klug, C. \& Korn, D. 2004: The origin of ammonoid locomotion. Acta Palaeontologica Polonica 49, 235-242.

Klug, C., Kröger, B., Korn, D., Rücklin, M., Schemm-Gregory, M., De Baets, K. \& Mapes, R.H. 2008a: Ecological change during the Early Emsian (Devonian) in the Tafilalt (Morocco), the origin of the Ammonoidea, and the first African pyrgocystid edrioasteroids, machaerids and phyllocarids. Palaeontographica A 283, $1-94$.

Klug, C., Meyer, E., Richter, U. \& Korn, D. 2008b: Soft-tissue imprints in fossil and Recent cephalopod septa and septum formation. Lethaia 41, 477-492.

Korn, D. \& Ilg, A. 2007: AMMON, http://www.wahre-staerke.com/ ammon/ [date of access: 26 November 2007].

Korn, D. \& Klug, C. 2002: Ammoneae devonicae. In Riegraf, W. (ed.): Fossilium Catalogus 1: Animalia 138, 1-375. Backhuys, Leiden.

Kröger, B. 2003: The size of siphuncle in cephalopod evolution. Senckenbergiana Lethaea 83, 39-52.

Kröger, B. 2005: Adaptive evolution in Paleozoic coiled cephalopods. Paleobiology 31, 253-268.

Kröger, B. 2008: Adaptive evolution in Palaeozoic coiled cephalopods. Special Papers in Palaeontology 79, 1-100.

Kröger, B. \& Mapes, R.H. 2007: On the origin of bactritoids. Paläontologische Zeitschrift 81, 316-327.

Kröger, B. \& Mutvei, H. 2005: Nautiloids with multiple paired muscle scars from Lower-Middle Ordovician of Baltoscandia. Palaeontology 48, 781-791.

Kröger, B., Klug, C. \& Mapes, R.H. 2005: Soft-tissue attachment in non-ammonoid cephalopods of Emsian to Eifelian age (Devonian). Acta Palaeontologica Polonica 50, 329-342.

Li, Y.X. 2000: Famennian tentaculitids of China. Journal of Paleontology 74, 969-975.

Long, J.A. 1993: Palaeozoic Vertebrate Biostratigraphy and Biogeography, 369 pp. Belhaven Press, London.

Long, J.A., Trinajstic, K., Young, G.C. \& Senden, T. 2008: Live birth in the Devonian. Nature 453, 650-652.

Madin, J.S., Alroy, J., Aberhan, M., Fürsich, F.T., Kiessling, W., Kosnik, M.A. \& Wagner, P.J. 2006: Statistical independence of escalatory ecological trends in Phanerozoic marine invertebrates. Science 312, 897-900.

Märss, T., Turner, S. \& Karatajute-Talimaa, V.N. 2007: Thelodonti. In Schultze, H.-P. (ed.): Handbook of Paleoichthyology $1 B, 1-199$. Fischer, Stuttgart \& New York.

Miller, R.F., Cloutier, R. \& Turner, S. 2003: The oldest articulated chondrichthyan from the Early Devonian period. Nature 425, 501.

Morrissey, L.B., Janvier, P., Braddy, S.J., Bennett, J.P., Marriott, S.B. \& Tarrant, P.R. 2006: Swimming with...Devonian fish. Geology Today 22, 66-67.

Mullins, G.L. \& Servais, T. 2008: The diversity of the Carboniferous phytoplankton. Review of Palaeobotany and Palynology 149, 2949.

Mutvei, H. 2002: Connecting ring structure and its significance for classification of the orthoceratid cephalopods. Acta Palaeontologica Polonica 47, 157-168.
Mutvei, H., Zhang, Y.-B. \& Dunca, E. 2007: Late Cambrian plectronocerid nautiloids and their role in cephalopod evolution. Palaeontology 50, 1327-1333.

Nützel, A. \& Frýda, J. 2003: Paleozoic plankton revolution: evidence from early gastropod ontogeny. Geology 31, 829-831.

Nützel, A., Lehnert, O. \& Frýda, J. 2007: Origin of planktotrophy evidence from early molluscs. Evolution and Development 9, 311-312.

Rigby, S. \& Rickards, B. 1989: New evidence for the life habit of graptoloids from physical modelling. Paleobiology 15, 402-413.

Rigby, S. \& Milsom, C.V. 2000: Origins, evolution, and diversification of zooplankton. Annual Review of Ecology and Systematics $31,293-313$

Sansom, I.J. \& Smith, M.M. 2001: The Ordovician radiation of vertebrates. In Ahlberg, E. (ed.): Major Events in Vertebrate Evolution, 156-171. Taylor \& Francis, London.

Seilacher, A. 1999: Biomat-related lifestyles in the Precambrian. Palaios 14, 86-93.

Sepkoski, J.J. Jr. 1984: A kinetic model of Phanerozoic taxonomic diversity. Paleobiology 10, 246-267.

Sepkoski, J.J. Jr. 2002: A Compendium of Fossil Marine Animal Genera. Bulletins of American Paleontology 363, 10-560.

Servais, T., Lehnert, O., Li, J., Mullins, G.L., Munnecke, A., Nützel, A. \& Vecoli, M. 2008: The Ordovician Biodiversification: revolution in the oceanic trophic chain. Lethaia 41, 99-109.

Servais, T., Harper, D.A.T., Li, J., Munnecke, A., Owen, A. \& Sheehan, P.M. 2009: Understanding the Great Ordovician Biodiversification Event (GOBE): influences of paleogeography, plaeoclimate, or paleoecology? GSA Today 19, 4-10.

Signor, P.W. III \& Brett, C.E. 1984: The mid-Paleozoic precursor to the Mesozoic marine revolution. Paleobiology 10, 229-245.

Signor, P.W. \& Vermeij, G. 1994: The plankton and the benthos: origins and early history of an evolving relationship. Paleobiology 20, 297-319.

Stanley, S.M. 2007: An analysis of the history of marine animal diversity. Paleobiology 33, 1-55.

Stridsberg, S. 1985: Silurian oncocerid cephalopods from Gotland. Fossils and Strata 18, 1-65.

Turner, S., Blieck, A.R.M. \& Nowlan, G.S. 2004: Cambrian-Ordovician vertebrates. In Webby, B. et al. (eds): The Great Ordovician Biodiversity Event. IGCP410, 327-335. Columbia University Press, New York.

Vermeij, G.J. 1977: The mesozoic marine revolution: evidence from snails, predators and grazers. Paleobiology 3, 245-258.

Wagner, P.J., Aberhan, M., Hendy, A. \& Kiessling, W. 2007: The effects of taxonomic standardization on sampling-standardized estimates of historical diversity. Proceedings of the Royal Society $B$ 207, 439-444.

Westermann, G.E.G. 1999. Life habits of nautiloids. In Savazzi, E. (ed.): Functional Morphology of the Invertebrate Skeleton, 236297. Wiley, Chichester.

Zangerl, R. 1981: Chondrichthyes I. In Schultze, H.-P. (ed.): Handbook of Paleoichthyology 3A,1-115. Fischer, Stuttgart \& New York.

Zhu, M. 2000: Catalogue of Devonian vertebrates of China, with notes on bio-events. Courier Forschungsinstitut Senckenberg 223, 373-390.

Zhu, M., Wang, N.-Z. \& W., J.-Q. 2000: Devonian macro- and microvertebrate assemblages of China. Courier Forschungsinstitut Senckenberg 223, 361-372. 